point of definite urbanization, fitting into the pattern the private and company libraries, the town and parish libraries, the social libraries, and the desire for publicly sponsored educational facilities.

The contents of the libraries of the time are not dealt with to any great extent, but short tables offer comparative bases for noting the percentile divisions of the small collections in to the various book categories. A consideration is also made of the early development of a form of special library among the social libraries which attempted to cater to the particular interests of its clientele. The aversion to fiction in the above mentioned collections also led to the early institution of the circulating library.

The author then traces the development of the public library through the steps toward municipal control, significance of the Boston Public Library, the beginnings of state legislation to the causal factors in public library development. In this last, the effects of economic ability, desire of scholarship, historical research, and the urge for conservation, work with the feeling of local pride and the increasingly felt need for universal public education, the Lyceum movement and vocational needs, to the end of setting up the first public libraries.

Professor Shera proves his thesis of the library as a social agency whose functions are only definitely known when the goals of society are certain. With its excellent index, selective bibliography, documents, plates, and charts this work is a worthy contribution to the University of Chicago Studies in Library Science, and one which we can hope will lead to an extended historical study of library development in conjunction with the country's expansion.-Harold L. Roth, Brooklyn Public Library.

\title{
Business Information
}

Sources of Business Information. By Edwin T. Coman, Jr. New York, Prentice-Hall, Inc., I949, ix, 406p. $\$ 6.00$; to schools, $\$ 4.50$.

Many efforts have been made to solve the bibliographic problem of organizing and listing sources of business information, but this is the first attempt to offer a critical, running commentary on the whole range of business literature. It is a courageous undertaking. As a handbook it should be very useful to students in schools of business, and, in some ways, to businessmen. It is certainly aimed at both groups. Whether this double-barrelled firing will exactly hit either group is a question that Coman at some time must have asked himself. The field of business information is large, the sources varied and occasionally obscure, and the bibliographic control inadequate. Special librarians are acutely conscious of these facts and spend many hours, and collectively a great deal of money to organize their resources to fit the particular business they serve. They know, too, that piling up references, or otherwise embarrassing their employers with the wealth of literature ingeniously discovered is seldom appreciated. Two of the requirements they have found are that the information supplied must exactly fit the particular need, and that it must be the latest.

To organize all business information for convenient use is a hopeless task. Either the coverage is broad, perhaps basic in some areas and superficial in others, or it is narrow and always shifting in time and boundary. Most bibliographies of business literature are merely handfuls of the swirling sands of fact and opinion. New facts or other theories. make them vanish in the desert of the superseded.

Coman has chosen the broad coverage. In limiting his choice of materials to the basic, he has avoided the criticism of incompleteness in the areas he covers. He has handled these competently by careful selection and brief, critical and descriptive comment. Only one who has struggled with organizing for use the vast and sometimes exasperating types of business materials can appreciate the extraordinary task he undertook. There are some important areas, however, and types of informational sources he has neglected. For example, the geographic factor is only slightly touched upon in the section on foreign trade, although it is as important for 
domestic as it is for foreign business. Corporation materials are slighted in both the section on financial information and that on accounting. The Securities and Exchange Commission's useful publications also are not mentioned. Another neglected source, used extensively in business, is supplementary contacts, which call for the citation of such aids as Who Knows-and What, and for statistics, the U. S. Budget Bureau's Federal Statistical Directory. In the section on advertising the directories of advertisers and agencies are not mentioned, though quite useful.

In spite of the care with which the bibliographic information was compiled, there are some errors which are hard to understand. Public Affairs Information Service bulletins are reported as appearing monthly instead of weekly, and the Dun and Bradstreet is listed as an annual. Surprising omissions are Nystrom's Marketing Handbook, Lasser's Handbook of Cost Accounting Methods, the more than locally useful Directory of Directors for the City of New York, Peterson's Handbook of Labor Unions, the National Association of Real Estate Boards' surveys, local real estate atlases, and that handbook useful for policy analysis, the Flitcraft Compend. A work of such proportions as this book must have been long in preparation, and for that reason the citation of earlier editions where later ones have been published must be due to the extreme difficulty of being sure that all entries are up to date when the book goes to press. Instances of this sort are the National Research Council's Handbook 1942 edition cited instead of the 1948, Who's Who in Commerce and Industry is noted in the 5th rather than the 6th edition; the League of Nations, Geneva, is given as publisher of the Monthly Bulletin of Statistics, instead of the present agency, the United Nations; the 1940 instead of the 1945 Census of Agriculture is noted on page 275; Aspley's Handbook of Industrial Relations is cited in both the 1943 and 1944 editions but not in the 3 rd, 1948 , edition. If the terminal date of compilation were mentioned in the preface, as it is not, the publication date of 1949 would not be so deceptive. Not as a matter of edition but of bringing the coverage to date, some reference should have been made to sampling, in spite of recent discredit of polling, since the technique will con- tinue to be used in many areas of business.

It is not clear from the nature of selections what audience the book is to reach: for the businessman without formal business education the sources seem profuse and the reading at times discouragingly difficult; for the businessman professionally educated many of the books may seem too elementary and the reference to sources too vague. There is, however, a core of useful reference books for either man, and, if one or the other is not bewildered by the too generous offering, he will use and appreciate that part of the book. Perhaps two volumes would have been more convenientone containing recommended reading for the mythical "average" businessman, and the other being a guide to business reference material. School of business students will appreciate this combination of basic reading and reference material. On the whole the book represents a good step forward in trying to help the uninitiated to master the various sources of business information.-Walter Hausdorfer, Temple University Libraries.

\section{OIT-0F PRINT and HAR[)-TO- FIND books sup-} plied. Also incomplete sets completed, genealogies and town histories, periodical back numbers, etc. All subjects, all languages. Send us your list of book-wants - no obligation. We report quickly. Lowest prices.

We have special runs of BOUND volumes of National Geographics, Natural History, Harpers Monthly, Readers Digests, St. Nicholas Magazines. Write for list with prices.

\section{AMERICAN LIBRARY SERVICE} 117 W. 48th St., Dept. L., New York 19, N.Y.

\section{P.S. We also buy books and magazines. Send us your list.}

N.B. We would appreciate if Librarians will kindly refer individuals seeking out of print books

to our service. 